\title{
The Selective Serotonin-2A Receptor Antagonist MI00907 Reverses Behavioral Deficits in Dopamine Transporter Knockout Mice
}

\author{
Alasdair M Barr', Virginia Lehmann-Masten², Martin Paulus ${ }^{2}$, Raul R Gainetdinov ${ }^{3}$, Marc G Caron ${ }^{3}$ and Mark \\ A Geyer, ${ }^{* 2}$ \\ 'Department of Neuropharmacology, The Scripps Research Institute, La Jolla, CA, USA; ${ }^{2}$ Department of Psychiatry, University of California at San \\ Diego, La Jolla, CA, USA; ${ }^{3}$ HHMI, Department of Cellular Biology \& Medicine, Duke University Medical Center, Durham, NC, USA
}

\begin{abstract}
A hyperdopaminergic state in humans has been hypothesized to contribute to the pathology of a number of psychiatric illnesses, including schizophrenia, bipolar disorder, and attention deficit hyperactivity disorder. Mice that display elevated synaptic levels of dopamine due to a genetically engineered deletion of the dopamine transporter (DAT) model behavioral deficits that simulate the above conditions. As novel treatment strategies for these disorders have focused on the serotonin (5-HT) 2A receptor, we determined the capacity of the highly selective $5-\mathrm{HT}_{2 \mathrm{~A}}$ receptor antagonist MI 00907 to reverse behavioral deficits in DAT knockout (KO) mice. Prior to drug treatment, DAT KO mice exhibited increased levels of locomotor activity and highly linearized movement in a novel environment, as well as reduced prepulse inhibition (PPI) of acoustic startle, compared to wild-type littermates. Treatment with MI 00907 (0.3-1.0 mg/ $\mathrm{kg}$, but not $0.1 \mathrm{mg} / \mathrm{kg}$ ) reversed locomotor deficits in DAT KO mice. Similarly, treatment with $1.0 \mathrm{mg} / \mathrm{kg}$ MI 00907 reversed the PPI deficits in DAT KO mice. These data indicate that selective 5- $\mathrm{HT}_{2 \mathrm{~A}}$ receptor antagonists, such as MI00907, may represent a class of drugs that can be used to treat conditions in which a chronic, elevated dopaminergic tone is present and contributes to abnormal behavior and sensorimotor gating deficits.

Neuropsychopharmacology (2004) 29, 22 I-228, advance online publication, 5 November 2003; doi: I 0. I038/sj.npp. I 300343
\end{abstract}

Keywords: animal model; behavior; dopamine transporter; mice; MI00907; serotonin-2A receptor; prepulse inhibition; startle

\section{INTRODUCTION}

The serotonin-2A $\left(5-\mathrm{HT}_{2 \mathrm{~A}}\right)$ receptor is a ubiquitous Gprotein-coupled receptor that is distributed widely throughout the central nervous system in mammals (Hoyer et al, $1996,2002)$. The $5-\mathrm{HT}_{2 \mathrm{~A}}$ receptor has been associated with a number of the more common psychiatric conditions, including major depression, obsessive-compulsive disorder, excessive impulsivity, anorexia nervosa, and schizophrenia (de Angelis, 2002). Converging lines of evidence, including linkage (Williams et al, 1996; although see Serretti et al, 2000), postmortem neurochemical (Burnet et al, 1996; Gurevich and Joyce, 1997), and neuroimaging studies (Ngan et al, 2000) suggest that the $5-\mathrm{HT}_{2 \mathrm{~A}}$ receptor may play an especially important role in the etiology of schizophrenia.

*Correspondence: Dr MA Geyer, Department of Psychiatry 0804, School of Medicine, University of California, San Diego, 9500 Gilman Drive, La Jolla, CA 92093-0804, USA, Tel: + I 619543 3582, Fax: + I 619543 2493, E-mail: mgeyer@ucsd.edu

Received 01 July 2003; revised 30 September 2003; accepted 03 October 2003

Online publication: 6 October 2003 at http://www.acnp.org/citations/ Npp I0060303029//default.pdf
The precise nature of the link between the $5-\mathrm{HT}_{2 \mathrm{~A}}$ receptor and schizophrenic symptomatology presently remains unclear, despite the above observations. Nevertheless, the $5-\mathrm{HT}_{2 \mathrm{~A}}$ receptor has become the focus of extensive research as a molecular target for the treatment of schizophrenia and associated psychotic disorders, for a number of reasons (Geyer, 1998). Firstly, psychoactive compounds with high affinity for the $5-\mathrm{HT}_{2 \mathrm{~A}}$ receptor, such as lysergic acid diethylamide (LSD) and $( \pm)-1$-(4-iodo2,5-dimethoxyphenyl)-2-aminopropane (DOI), exhibit potent hallucinogenic properties (Geyer, 1998; Aghajanian and Marek, 1999), which have been suggested to mimic aspects of the positive symptoms of schizophrenia. Secondly, most atypical antipsychotic drugs display a high affinity for the $5-\mathrm{HT}_{2 \mathrm{~A}}$ receptor in addition to the dopamine $\mathrm{D}_{2}$ receptor (Meltzer, 1999; Scatton and Sanger, 2000). Thirdly, the $5-\mathrm{HT}_{2}$ subclass of receptors is densely expressed in many brain regions, including the striatum (Bubser et al, 2001) and prefrontal cortex (Jakab and Goldman-Rakic, 1998), and may modulate dopaminergic neurotransmission in limbic brain regions, such as the nucleus accumbens and prefrontal cortex (eg Lucas and Spampinato, 2000). Given the hypothetical role for a state of hyperdopaminergia in 
schizophrenia (Laruelle, 2000), the ability of these compounds to modify mesolimbic dopamine transmission highlights their importance as drugs with potential antipsychotic activity. Furthermore, 5- $\mathrm{HT}_{2 \mathrm{~A}}$ receptors can potently influence glutamate transmission in the frontal cortex, thereby affecting frontostriatal glutamatergic pathways, the dysfunction of which constitutes another major explanatory hypothesis of schizophrenia (Aghajanian and Marek, 2000).

The putative antipsychotic drug $R(+)$-alpha-(2,3-dimethoxyphenyl)-1-[2-(4-fluorophenylethyl)]-4-piperidinemethanol (M100907) is a highly selective $5-\mathrm{HT}_{2 \mathrm{~A}}$ receptor antagonist with significantly greater affinity $(>500$-fold) for the $5-\mathrm{HT}_{2 \mathrm{~A}}$ receptor over the $\mathrm{D}_{2}$ receptor (Palfreyman et al, 1993; de Paulis, 2001), which may underlie its ability to achieve a high level of receptor occupancy in the absence of extrapyramidal-like symptoms in humans (Andree et al, 1998). M100907 has been shown to elicit a positive response in a large number of preclinical paradigms designed to detect antipsychotic activity (Kehne et al, 1996). Several of these rodent paradigms indicate that M100907 can reverse the behavioral effects of an acute hyperdopaminergic state that has been induced by amphetamines (Sorensen et al, 1993), potentially through modification of stimulated release of dopamine in the medial prefrontal cortex (Pehek et al, 2001) and nucleus accumbens shell (Marcus et al, 2000).

In consideration of the above information, it would clearly be of interest to determine the capacity of M100907 to reverse the behavioral effects of a hyperdopaminergic state in a chronic, nonpharmacological model. Such an opportunity is afforded by the use of mice with a selective deletion of the gene for the dopamine transporter (DAT), which exhibits elevated interstitial levels of dopamine, as well as a range of behavioral deficits including locomotor hyperactivity (Gainetdinov et al, 1999). DAT KO mice also display consistent deficits in a sensorimotor gating task, namely prepulse inhibition (PPI) of the acoustic startle reflex. PPI of the acoustic startle reflex refers to the reduction in startle magnitude that occurs following the presentation of a brief, nonstartling stimulus (Hoffman and Ison, 1980). Prepulse inhibition deficits are frequently observed in psychotic disorders, such as schizophrenia (Braff et al, 2001), and have been modeled in rodents following treatment with psychotomimetic drugs, such as $d$ amphetamine (Geyer et al, 2001), that raise synaptic levels of dopamine to levels similar to those of DAT KO mice. Hence, in the present study, we have examined the capacity of the putative antipsychotic M100907 to reverse the locomotor and PPI deficits in DAT KO mice.

\section{MATERIALS AND METHODS}

\section{Subjects}

For all experiments, WT and KO DAT mice were bred at the San Diego Veteran's Administration Medical Center in an Association for Assessment and Accreditation of Laboratory Animal Care-approved animal facility, which met all state and federal requirements for animal care, using parental mice received from Duke University (Giros et al, 1996). Mouse pups were weaned at 28 days and were housed in groups of two to four (segregated by sex), in a temperatureand light-controlled colony (lights on at $1900 \mathrm{~h}$, lights off at $0700 \mathrm{~h}$ ), with food and water available ad libitum. All behavioral testing commenced no earlier than 8-9 weeks of age. Separate cohorts of mice were used for different experiments. For Experiment 1, $19 \mathrm{WT}$ and $11 \mathrm{KO}$ mice were the subjects. Experiment 2 consisted of $35 \mathrm{WT}$ and 11 KO mice. Experiment 3 consisted of $32 \mathrm{WT}$ and $10 \mathrm{KO}$ mice. For experiment 4, $24 \mathrm{WT}$ and $17 \mathrm{KO}$ mice were used.

\section{Drugs}

M100907 (Hoechst Marion Roussel, Inc., USA) was dissolved in a warm, 5\% Tween 80 (Sigma, USA) solution of distilled water. Drug was administered subcutaneously to all animals, in a volume of $5 \mathrm{ml} / \mathrm{kg}$.

\section{Apparatus}

Eight startle chambers were used to measure the startle response (SR-LAB, San Diego Instruments, San Diego, CA). Each chamber consisted of a nonrestrictive Plexiglas $^{\mathrm{TM}}$ cylinder mounted on a frame inside a lit, ventilated box $\left(39 \times 38 \times 58 \mathrm{~cm}^{3}\right)$. Movements within the cylinder were detected by a piezoelectric accelerometer that was attached beneath the cylinder. Vibrations detected by the accelerometer were transduced into analog electrical signals that were subsequently digitized and stored by the computer. In all, 65 readings were recorded at $1 \mathrm{~ms}$ intervals, commencing at stimulus onset, and the average amplitude was used to describe the acoustic startle response. A high-frequency loudspeaker inside the box, mounted $24 \mathrm{~cm}$ above the chamber, generated the broadband background noise and acoustic stimuli, which were controlled by the SR-LAB software system and interface. Sound levels ( $\mathrm{dB}(\mathrm{A})$ scale) and accelerometer sensitivities were monitored routinely, as described previously (Dulawa et al, 1997), to ensure consistent sensitivities across test sessions (Swerdlow and Geyer, 1998).

Locomotor activity was measured using the VideoTracker (VT) system, which consisted of four adjacent white plastic enclosures $\left(41 \times 41 \times 34 \mathrm{~cm}^{3}\right)$ located at the floor level, that were surrounded by an opaque plastic curtain. Mice were placed separately into an individual enclosure, and at no time were ever in contact with other animals. Enclosures were wiped clean between each test session, to remove residual odors. A video camera, mounted $158 \mathrm{~cm}$ above the enclosures, generated the signal for the Polytrack ${ }^{\complement}$ digitizer (San Diego Instruments). Signals were processed to acquire the left-uppermost coordinate for each of the four animals simultaneously; these data were then stored in a PC computer for subsequent off-line processing and analysis. The position of each animal $(x, y)$ (in pixels) was sampled with a frequency of $18.18 \mathrm{~Hz}$, which was used to generate a coordinate file $(x, y, t)$ consisting of the $x$-location, $y$-location and the duration (time $t$ ) spent in that location. Each enclosure was further subdivided for analysis by the software into nine equally sized square regions. The spatio-temporal resolution of each recorded event was $0.32 \mathrm{~cm} \times 0.32 \mathrm{~cm} \times 55 \mathrm{~ms}$, corresponding to a maximum speed of $25 \mathrm{~cm} / \mathrm{s}$. 


\section{Experimental Procedure}

Experiment 1. For the acoustic startle experiments, mice were tested initially in a baseline PPI session and divided into groups for subsequent drug treatment, based on measures of PPI and startle magnitude, in a balanced order. For the main experiments, mice were treated with either vehicle or M100907 ( 0.3 or $1.0 \mathrm{mg} / \mathrm{kg}) 30 \mathrm{~min}$ before testing. The experimental session consisted of a $10 \mathrm{~min}$ acclimatization period in which only broadband background noise $(65 \mathrm{~dB})$ was presented. The acclimatization was followed by a PPI session that consisted of five different trial types: no stimulus trials (NOSTIM); a startle pulse alone trial of $40 \mathrm{~ms}$ at $120 \mathrm{~dB}$ (P120); and three prepulse + pulse trials of a $20 \mathrm{~ms}$ noise prepulse at either 69,73 , or $81 \mathrm{~dB}$, followed by a $80 \mathrm{~ms}$ delay, then a $40 \mathrm{~ms} 120 \mathrm{~dB}$ startle pulse. The NOSTIM trial consisted of only background broadband noise. All test sessions commenced and concluded with five presentations of the P120 trial, while the remainder of the session consisted of 10 presentations of each trial type in a pseudorandom order, with varying intertrial intervals (mean $15 \mathrm{~s}$, range $12-30 \mathrm{~s}$ ). Each animal was always tested in the same startle chamber.

\section{Experiments 2-4}

Locomotor activity sessions consisted of treatment with either vehicle or M100907 in separate cohorts of mice $(0.1 \mathrm{mg} / \mathrm{kg}$ (experiment 2), $0.3 \mathrm{mg} / \mathrm{kg}$ (experiment 3 ) or $1.0 \mathrm{mg} / \mathrm{kg}$ (experiment 4)) $30 \mathrm{~min}$ prior to testing. In each cohort, a within-subjects crossover design was used. Mice were allowed at least 2 weeks prior to retesting with the alternate treatment. For testing, each mouse was placed in the bottom-left-hand corner of an enclosure at the start of the 60 -min test session. Two general categories of movement were obtained: the first consisted of measures of overall locomotor activity, which represented the total distance traveled within and between each of the nine regions of the enclosure. The second category of movements consisted of the geometric pattern of locomotor activity, as quantified by the spatial scaling exponent, $d$, as described in detail elsewhere (Paulus and Geyer, 1991). In brief, the scaling exponent quantifies the extent to which a series of movements falls along a straight line $(d=1)$ or within a circumscribed area $(d=2)$.

\section{Data and Statistical Analysis}

Prepulse inhibition was calculated as a percentage score for each prepulse intensity by the equation: \% PPI $=100-$ $\{($ startle response for prepulse + pulse trials (PP4, PP8 or $\mathrm{PP} 16)) /($ startle response for pulse alone $(\mathrm{P} 120)) \times 100\}$.

The startle magnitude was calculated as the average of all pulse alone trials, excluding the first and last five such trials in each session. Data were analyzed using the BMDP statistical package (SPSS, Inc., Chicago, IL). ANOVAs were performed on the data for acoustic startle experiments, with treatment and genotype as between-subjects factors and prepulse intensity as a within-subject factor (preliminary analysis of data indicated that there was no significant main effect or interactive effects of gender; so data from both sexes were combined). Locomotor activity data from each cohort of mice were subjected to separate two-factor ANOVAs, with genotype as a between-subjects factor and drug treatment as a within-subjects factor. Where applicable, Tukey's tests were conducted for post hoc analysis.

\section{RESULTS}

\section{Experiment 1}

As observed previously (Ralph et al, 1999), DAT mice exhibited a profound deficit in sensorimotor gating, as measured by decreased PPI of the acoustic startle reflex (Figure 1). The results of the ANOVA revealed that there was a significant main effect of genotype on PPI $\left(\mathrm{F}_{(1,75)}=14.27 ; p<0.001\right)$, with no significant interaction of genotype by prepulse intensity $\left(\mathrm{F}_{(2,150)}=0.14\right.$; NS). The ANOVA also revealed a significant genotype by treatment interaction $\left(\mathrm{F}_{(2,75)}=5.48 ; p<0.01\right)$, revealing the ability of M100907 to reverse selectively the PPI deficits in DAT KO mice. Post hoc comparisons revealed that DAT KO mice displayed significantly reduced levels of PPI across all prepulse intensities, compared to WT mice (pp4: $\mathrm{F}_{(1,75)}=8.47 ; p<0.01 ; \mathrm{pp} 8: \mathrm{F}_{(1,75)}=11.28 ; p<0.01 ; \mathrm{pp} 16$ : $\left.\mathrm{F}_{(1,75)}=12.09 ; p<0.001\right)$. Reduced levels of PPI in DAT KO mice were not associated with altered levels of startle reactivity (Table 1). In addition, the $1.0 \mathrm{mg} / \mathrm{kg}$ dose of M100907 reversed the DATKO PPI deficit (pp4: $\mathrm{F}_{(2,56)}=3.97 ; p=0.05 ; \mathrm{pp} 8: \mathrm{F}_{(2,56)}=10.11 ; p<0.01 ; \mathrm{pp} 16$ : $\mathrm{F}_{(2,56)}=13.08 ; p<0.001$ ) (Figure 1 ). There was no significant effect of M100907 treatment on startle $\left(\mathrm{F}_{(2,75)}=\right.$ 1.29 ; NS).

\section{Experiment 2}

Consistent with previous observations (Ralph et al, 2001), DAT KO mice exhibited striking differences in the pattern and sequential organization of their behavior. Most noticeably, DAT KO mice were hyperactive in the novel environment, as they displayed elevated levels of locomotor activity, revealed by the ANOVA as a significant main effect of genotype on the distance traveled $\left(\mathrm{F}_{(1,39)}=15.84\right.$; $p<0.001)$. Pretreatment with a low dose of $0.1 \mathrm{mg} / \mathrm{kg}$ M100907 failed to affect the distance traveled by mice

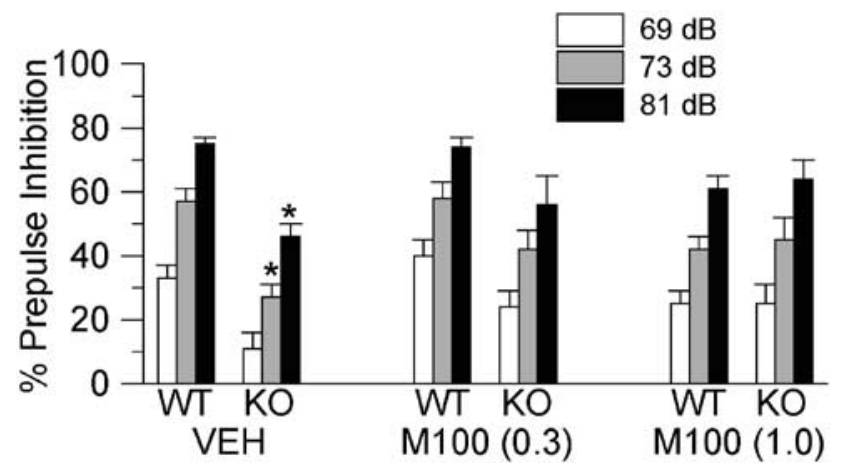

Figure I Prepulse inhibition in DAT WT and DAT KO mice after administration of either vehicle, 0.3 or $1.0 \mathrm{mg} / \mathrm{kg}$ MI 00907. DAT KO mice displayed significantly reduced PPI across all prepulse intensities. The $1.0 \mathrm{mg} / \mathrm{kg}$ dose of MI00907 significantly reversed the PPI deficits in DAT $\mathrm{KO}$ mice. 
$\left(F_{(1,39)}=0.20 ; \quad N S\right)$, or generate a significant genotype $\times$ treatment interaction $\left(\mathrm{F}_{(1,39)}=0.17\right.$; NS).

In addition to the increased overall levels of locomotor activity in DAT KO mice, these animals displayed a distinct difference in the two-dimensional geometric pattern of their locomotor activity. Whereas WT mice exhibited a combination of straight, meandering, and circuitous movements within the enclosure, $\mathrm{KO}$ mice engaged in far more linearized and less tortuous movement as they typically followed the perimeter of the square enclosure. This aspect of spatial activity, described quantitatively by the spatial scaling exponent, $d$, was reduced significantly in DAT KO mice compared to $\mathrm{WT}$ mice $\left(\mathrm{F}_{(1,39)}=70.87 ; p<0.0001\right)$, indicating that that behavioral repertoire of the $\mathrm{KO}$ mice was more restricted, and was reflected in large part by a high degree of locomotor perseveration; the pretreatment with $0.1 \mathrm{mg} / \mathrm{kg}$ of M100907 failed to have a significant effect on spatial $d\left(\mathrm{~F}_{(1,39)}=0.67 ; \mathrm{NS}\right)$ or interactive effect with genotype $\left(\mathrm{F}_{(1,39)}=3.16\right.$; NS) (Table 2$)$.

\section{Experiment 3}

Consistent with the results of the prior experiment, the DAT $\mathrm{KO}$ mice in this cohort of animals displayed a significant main effect of genotype on distance traveled within the enclosure $\left(\mathrm{F}_{(1,38)}=40.54 ; p<0.0001\right)$, as their levels of

Table I Effects of MI00907 on Acoustic Startle Reactivity in DAT $\mathrm{WT}$ and $\mathrm{KO}$ Mice

\begin{tabular}{lrr}
\hline & DATWT & \multicolumn{1}{c}{ DATKO } \\
\hline VEH & $112.1 \pm 17.2$ & $118.0 \pm 16.2$ \\
$0.3 \mathrm{mg} / \mathrm{kg} \mathrm{MI00907}$ & $115.4 \pm 22.1$ & $81.9 \pm 22.4$ \\
$1.0 \mathrm{mg} / \mathrm{kg}$ MI00907 & $96.8 \pm 21.2$ & $75.2 \pm 14.7$ \\
\hline
\end{tabular}

Values (arbitrary units) represent mean startle magnitude \pm SEM. locomotor activity were more than twice those of WT mice. The effects of treatment with a $0.3 \mathrm{mg} / \mathrm{kg}$ dose of M100907 were revealed as a significant main effect of the drug on distance traveled $\left(\mathrm{F}_{(1,38)}=25.91 ; p<0.0001\right)$. The ANOVA confirmed a significant interaction between genotype and treatment on the distance traveled $\left(\mathrm{F}_{(1,38)}=9.43 ; p<0.01\right)$. Subsequent analyses of the interaction with post hoc test revealed that $0.3 \mathrm{mg} / \mathrm{kg}$ M100907 selectively attenuated the distance traveled by DAT KO mice, although not to the levels of WT animals.

In parallel with the prior cohort of mice, DAT KO mice exhibited significantly reduced values of spatial $d$, $\left(\mathrm{F}_{(1,38)}=33.87 ; p<0.0001\right)$. Although the ANOVA indicated a significant main effect of drug treatment on spatial $d$, $\left(\mathrm{F}_{(1,38)}=19.59 ; p<0.001\right)$, there was no significant interaction of genotype $\times$ treatment $\left(\mathrm{F}_{(1,38)}=0.93 ; \mathrm{NS}\right)$, as $0.3 \mathrm{mg} / \mathrm{kg} \mathrm{M} 100907$ increased $d$ values in both $\mathrm{KO}$ and WT mice (Table 3).

\section{Experiment 4}

As with prior cohorts, the DAT KO mice in this experiment exhibited significantly greater locomotor activity, indicated by ANOVA as a main effect of genotype in the total distance traveled within the enclosure $\left(\mathrm{F}_{(1,34)}=6.37 ; p<0.05\right)$. Treatment with $1.0 \mathrm{mg} / \mathrm{kg}$ M100907 generated a significant main effect of treatment on distance traveled $\left(\mathrm{F}_{(1,34)}=11.12\right.$; $p<0.001)$ and a genotype $\times$ treatment interaction $\left(\mathrm{F}_{(1,34)}=13.17 ; p<0.001\right)$. Analysis of the interaction with subsequent post hoc tests revealed that $1.0 \mathrm{mg} / \mathrm{kg} \mathrm{M100907}$ completely reversed the hyperlocomotion of DAT KO mice to the levels of WT mice, without having any effect on the activity of the latter animals.

The present cohort of mice also displayed the predicted reduction in spatial- $d$ values in DAT KO mice $\left(\mathrm{F}_{(1,34)}=\right.$ 20.09; $p<0.0001)$. Treatment with $1.0 \mathrm{mg} / \mathrm{kg} \mathrm{M} 100907$ generated a significant main effect $\left(\mathrm{F}_{(1,34)}=51.77\right.$; $p<0.0001)$ and a significant interaction of genotype $\times$

Table 2 Effects of MI00907 on Distance Traveled in DAT WT and KO Mice

\begin{tabular}{lcccc}
\hline & DATWT/VEH & DATKO/VEH & DATWT/MI00 & DATKO/MI00 \\
\hline $\operatorname{EXP} 2(0.1 \mathrm{mg} / \mathrm{kg})$ & $21394 \pm 6099$ & $68711 \pm 13881$ & $16895 \pm 6717$ & $68532 \pm 14837$ \\
$\operatorname{EXP~} 3(0.3 \mathrm{mg} / \mathrm{kg})$ & $21495 \pm 4934$ & $102482 \pm 18468$ & $13487 \pm 2641$ & $70127 \pm 16300 *$ \\
$\operatorname{EXP} 4(1.0 \mathrm{mg} / \mathrm{kg})$ & $17401 \pm 1984$ & $51567 \pm 10215$ & $19118 \pm 5605$ & $10977 \pm 2732 *$ \\
\hline
\end{tabular}

Values represent mean \pm SEM. ${ }^{*} p<0.05$ treatment by gene interaction.

Table 3 Effects of MI00907 on Spatial d in DAT WT and KO Mice

\begin{tabular}{|c|c|c|c|c|}
\hline & DATWT/VEH & DATKO/VEH & DATWT/MIO0 & DATKO/MIOO \\
\hline EXP $2(0.1$ mg/kg) & $1.690 \pm 0.028$ & $1.364 \pm 0.05 \mid$ & $1.768 \pm 0.026$ & $1.335 \pm 0.048$ \\
\hline EXP $3(0.3$ mg/kg) & $1.684 \pm 0.029$ & $1.325 \pm 0.060$ & $1.765 \pm 0.027$ & $1.452 \pm 0.086$ \\
\hline EXP $4(1.0 \mathrm{mg} / \mathrm{kg})$ & $1.642 \pm 0.032$ & $1.421 \pm 0.032$ & $1.831 \pm 0.035$ & $1.790 \pm 0.038 *$ \\
\hline
\end{tabular}

Values represent mean \pm SEM. $* P<0.05$ treatment by gene interaction. 

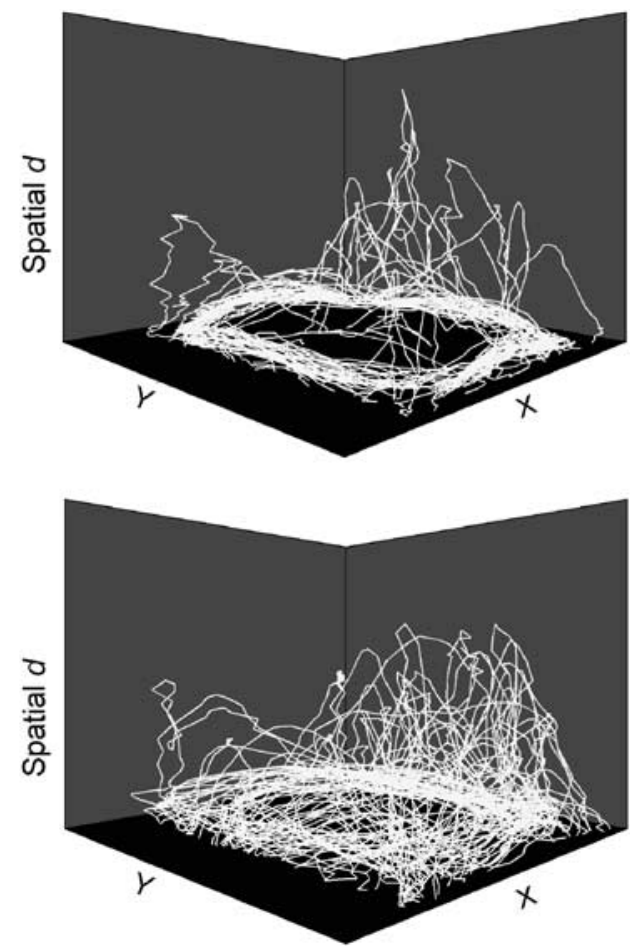

Figure 2 Initial $10 \mathrm{~min}$ in the video-tracking chamber of a DAT KO mouse after administration of either vehicle (top) or $1.0 \mathrm{mg} / \mathrm{kg}$ MI00907 (bottom). The $x y$ positions of the mouse are represented in the $x y$-plane. The spatial $d$ value at each $x y$ position is represented on the $z$-plane. MI00907 reduces the perseveration of linear movements characteristic of DATKO mice.

treatment $\left(\mathrm{F}_{(1,34)}=5.46 ; p<0.05\right)$, indicating that $\mathrm{M} 100907$ alters the perseverative locomotor behavior of DAT KO mice (Table 2, Figures 2 and 3 ).

\section{DISCUSSION}

In the present study, we have confirmed previous findings that mice with a genetic deletion of the DAT exhibit profound deficits in PPI, as well as substantially elevated locomotor activity, compared to their WT and HT siblings (Giros et al, 1996; Ralph et al, 2001). Knockout DAT mice displayed significantly reduced levels of PPI across all prepulse intensities, without concomitant alterations in startle reactivity. Furthermore, we demonstrate for the first time that these PPI deficits can be reversed by the selective $5-\mathrm{HT}_{2 \mathrm{~A}}$ receptor antagonist M100907. Similarly, DAT KO mice displayed elevated levels of locomotor activity during exposure to a novel environment, which was also reversed by M100907 at doses that were without effect in WT mice.

The results of the present experiments are in general agreement with those of prior studies. Elevated locomotor activity is one of the more consistent behavioral phenotypic traits of DAT KO mice (Giros et al, 1996; Spielewoy et al, 2000; Gainetdinov et al, 2001); in the present study, these mice exhibited levels of activity in a novel environment, that is, their total distance traveled two to three times those of WT and HT mice. The finding that M100907 can reverse hyperactivity selectively in DAT KO mice, which have elevated synaptic levels of dopamine (Gainetdinov et al,

\section{Behavioral Effect of M100907}

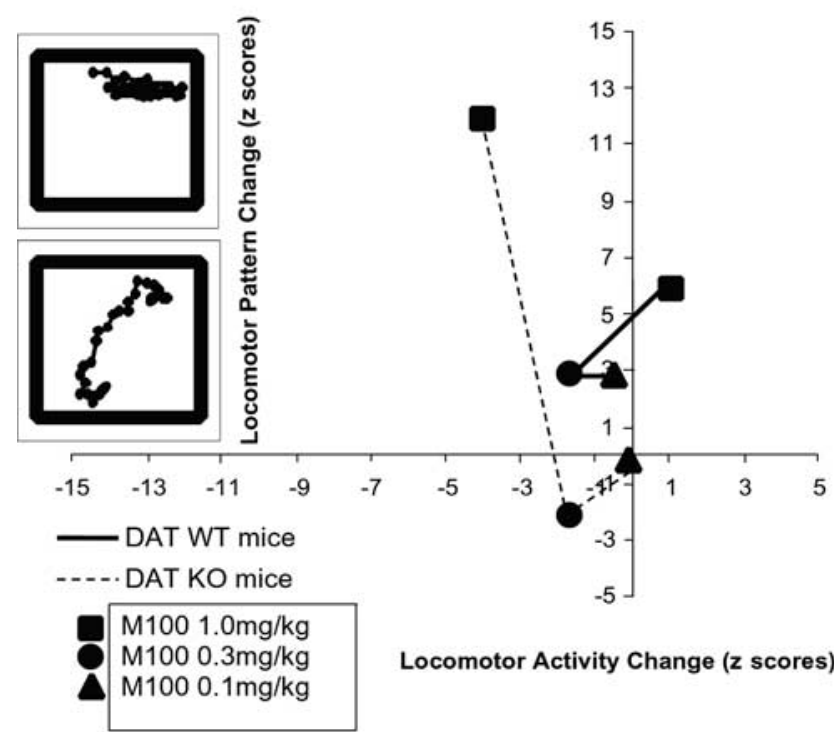

Figure 3 Effect size of MI00907 on the amount of locomotor activity (x-axis) and the patterns of locomotor activity (y-axis). The inset shows a segment with circumscribed movements (high spatial $d$ values) and with straight repetitive movements (low spatial $d$ values), respectively. The effect sizes of the three doses of MI00907 on both locomotor activity and spatial patterns of movements in both wild-type and knockout mice are significantly larger in the pattern domain than in the locomotor domain. Nevertheless, MI00907 changed the combination of locomotor activity and movement patterns in a similar direction for both wild-type and knockout mice, toward more circumscribed less repetitive movement patterns.

1999), complements earlier reports that M100907 reverses the behavioral hyperactivity induced by indirect dopamine agonists, such as cocaine, $d$-amphetamine and GBR 12909, in both rats and mice (Sorensen et al, 1993; Carlsson, 1995; Kehne et al, 1996; O’Neill et al, 1999; McMahon and Cunningham, 2001). Although the between-cohorts design of the locomotor tasks in the present study, using different cohorts of mice with different doses, precluded an explicit test of dose-dependency of M100907, the greater relative effect size of the highest dose strongly suggests that behavioral effects were dose related. Additional support for a role for the $5-\mathrm{HT}_{2 \mathrm{~A}}$ receptor in modulation of dopamine-induced hyperactivity in DAT KO mice is indicated by the capacity of the $5-\mathrm{HT}_{2 \mathrm{~A}}$ receptor antagonist ketanserin to reduce significant locomotion at doses of 0.4 and $2.0 \mathrm{mg} / \mathrm{kg}$ (Gainetdinov et al, unpublished results). However, in apparent contrast to the present results, Carlsson et al (1999) previously observed no significant effect of M100907 on amphetamine-induced hyperactivity in mice. While animal strain differences and other minor methodological differences may account for this discrepancy, a more likely explanation rests with the difference in dosing schedules used in the two studies: Carlsson et al administered substantially lower doses of M100907, between 0.001 and $0.1 \mathrm{mg} / \mathrm{kg}$, whereas the lowest behaviorally active dose in the current study was $0.3 \mathrm{mg} / \mathrm{kg}$.

Consistent with previous results (Ralph et al, 2001), DAT $\mathrm{KO}$ mice in all cohorts of the present study displayed a reliable deficit in the spatial scaling exponent $d$. This 
measure provides a sophisticated description of the geometric pattern of locomotor activity exhibited by rodents in a novel environment (Paulus and Geyer, 1991). The reduced $d$ values of DAT KO mice indicate that one form of perseveration, whereby locomotion is limited largely to a highly linear movement, as opposed to perseveration consisting of repetitive focal movements, was significantly increased (Paulus and Geyer, 1991). Previously, we demonstrated that this behavioral deficit in DAT KO mice could be attenuated by treatment with the selective $\mathrm{D}_{1}$ antagonist $\mathrm{SCH} 23390$, but not with the $\mathrm{D}_{2}$ antagonist raclopride (Ralph et al, 2001). The capacity of M100907 to reverse low $d$ values in DAT KO mice at a dose of $1 \mathrm{mg} / \mathrm{kg}$ in the current study is unlikely to be mediated by its low affinity for the $D_{1}$ receptor. Instead, it may represent a previously unreported functional property of antagonism at the $5-\mathrm{HT}_{2 \mathrm{~A}}$ receptor, and would be consistent with the use of drugs with $5-\mathrm{HT}_{2 \mathrm{~A}}$ antagonism to treat disorders in which a high degree of perseveration is evident, such as schizophrenia and autism (Meltzer, 1999; Barnard et al, 2002). Moreover, the larger effect size on the spatial patterns of movements $v s$ locomotion may indicate that $5-\mathrm{HT}_{2 \mathrm{~A}}$ receptor activity regulates the degree of perseveration more sensitively than the degree of overall locomotor activity.

The capacity of M100907 to reverse PPI deficits in DAT KO mice is also consistent with prior studies that have demonstrated that sensorimotor gating deficits can be reversed by the drug. The PPI-disruptive effects of both DOI (Padich et al, 1996; Sipes and Geyer, 1997) and dizocilpine (Varty et al, 1999) are potently reversed by M100907, although its capacity to reverse PPI deficits caused by a pharmacologically induced hyperdopaminergic state, such as through the use of amphetamines, remains unknown. In addition, M100907 exhibits positive responses in a number of alternative preclinical models used for the detection of antipsychotic compounds, including disruption of latent inhibition (Moser et al, 1996) and potentiation of the effects of typical antipsychotics in the conditioned avoidance response task (Wadenberg et al, 1998, 2001).

The precise physiological mechanisms by which M100907 is able to reverse the behavioral alterations in DAT KO mice remain unknown. We have shown previously (Ralph et al, 2001) that the behavioral hyperactivity in DAT KO mice is reversed with both dopamine $D_{1}$ and $D_{2}$ antagonists, while PPI deficits are reversed only with $\mathrm{D}_{2}$ antagonists. It is unlikely that M100907 exerts its actions directly at dopamine receptors, as the compound exhibits a low binding affinity for these receptors (Kehne et al, 1996). Furthermore, M100907 was unable to reverse the hyperlocomotor effects of the direct $\mathrm{D}_{1}$ agonist C-APB (O'Neill et al, 1999) in WT mice, while a dose of M100907 as high as $32 \mathrm{mg} / \mathrm{kg}$ was ineffective in countering the behavioral effects of the direct $\mathrm{D}_{2}$ agonist apomorphine in mice. Studies using in vivo techniques, such as cerebral microdialysis, have suggested that M100907 can reduce impulse-dependent dopamine release in the rat medial prefrontal cortex (Pehek et al, 2001), while the selective $5-\mathrm{HT}_{2 \mathrm{~A}}$ receptor antagonist SR 46349B attenuated amphetamine-induced dopamine release in the nucleus accumbens and dorsal striatum (Porras et al, 2002). The authors of these studies have posited that the $5-\mathrm{HT}_{2 \mathrm{~A}}$ receptor exerts a minimal influence on basal dopamine efflux, hence explaining why no effects of M100907 were observed in WT animals in the present study, but may modulate dopamine release under conditions when the mesocortical system is stimulated.

However, while it is likely that M100907 reverses the behavioral deficits in DAT KO mice by modifying the presumed cause of the deficits, namely increased levels of synaptic dopamine, additional possibilities should be considered. Knockout DAT mice exhibit a number of pleiotropic developmental alterations (reviewed in Gainetdinov et al, 2002), including an increased sensitivity to blockade of $N$-methyl- $d$-aspartate (NMDA) receptormediated glutamatergic transmission (Gainetdinov et al, 2001). As a number of recent studies have demonstrated that M100907 is either equally so or more effective at reversing behavioral deficits in hypoglutamatergic compared to hyperdopaminergic mice (Carlsson et al, 1999; O' Neill et al, 1999), the possibility that M100907 exerts its behavioral effects through glutamatergic signaling should be considered.

The results of the present study indicate that $5-\mathrm{HT}_{2 \mathrm{~A}}$ receptor antagonists such as M100907 may have therapeutic potential for the treatment of human disorders in which hyperactivity and deficits in sensorimotor gating occur, especially when such indications reflect an underlying aberration in dopaminergic neurophysiology, such as may occur in schizophrenia (Laruelle, 2000). Due to its high selectivity for the $5-\mathrm{HT}_{2 \mathrm{~A}}$ receptor, which has been considered an important molecular target for the development of antipsychotic drugs (Meltzer, 1999), M100907 has become the focus of intense interest as the first in its novel class of drugs for the treatment of schizophrenia. The very low affinity of M100907 for dopamine receptors in humans ensures that the common side effects typically associated with neuroleptics, such as extrapyramidal symptoms and hyperprolactinemia (Remington and Kapur, 2000), do not arise significantly at physiologically relevant doses (Offord et al, 1999; Talvik-Lotfi et al, 2000). Presently, human trials with M100907 in a broad spectrum of neuroleptic-responsive schizophrenia patients have provided mixed results (de Paulis, 2001), and the compound does not appear to offer superior clinical efficacy compared to traditional neuroleptics. Nevertheless, findings from preclinical studies, in which M100907 augments the behavioral and neurochemical effects of typical antipsychotics such as haloperidol (Wadenberg et al, 2001; Liegeois et al, 2002), suggest that such drugs may be useful when administered as an adjunct to neuroleptic treatment, potentially reducing the dose of the latter necessary for treatment.

The behavioral deficits and hyperdopaminergia exhibited by DAT KO mice are also of relevance to other human disorders. For instance, DAT KO mice have been hypothesized to represent an animal model of attention-deficit hyperactivity disorder (ADHD) (Gainetdinov et al, 1999), and the ability of M100907 to reverse behavioral alterations in these animals raises the possibility that it may characterize a novel class of drugs with low side-effect profile and minimal potential for substance abuse that are efficacious in this disorder. Intriguingly, association of the $5-\mathrm{HT}_{2 \mathrm{~A}}$ receptor gene polymorphism with $\mathrm{ADHD}$ has been recently reported (Levitan et al, 2002). Furthermore, the behavioral phenotype of DAT KO mice also closely resembles that of bipolar depressive disorder in humans, 
as both exhibit general hyperactivity and deficits in PPI (Perry et al, 2001). The capacity of standard treatments for bipolar disorder, such as lithium, carbamazepine, and valproate, to reverse behavioral deficits in DAT KO mice remains to be determined in the further validation of these mice as a model of human disease.

\section{ACKNOWLEDGEMENTS}

We thank Mr David Gallagher for his technical assistance. We would also like to thank Dr Susan B Powell and Mr Jacob Ong for their helpful comments on the manuscript. These studies were supported by the Veterans Affairs VISN 22 Mental Illness Research, Education, and Clinical Center, and grants from the National Institute on Drug Abuse (DA02925 (MAG)) and the National Institute of Mental Health (MH61326 (MAG) and MH60451 (MGC)). MA Geyer holds an equity interest in San Diego Instruments.

\section{REFERENCES}

Aghajanian GK, Marek GJ (1999). Serotonin and hallucinogens. Neuropsychopharmacology 21: 16S-23S.

Aghajanian GK, Marek GJ (2000). Serotonin model of schizophrenia: emerging role of glutamate mechanisms. Brain Res Rev 31: 302-312.

Andree B, Nyberg S, Ito H, Ginovart N, Brunner F, Jaquet F et al (1998). Positron emission tomographic analysis of dose-dependent MDL 100,907 binding to 5-hydroxytryptamine-2A receptors in the human brain. J Clin Psychopharmacol 18: 317-323.

Barnard L, Young AH, Pearson J, Geddes J, O’Brien G (2002). A systematic review of the use of atypical antipsychotics in autism. J Psychopharmacol 16: 93-101.

Braff DL, Geyer MA, Swerdlow NR (2001). Human studies of prepulse inhibition of startle: normal subjects, patient groups, and pharmacological studies. Psychopharmacology 156: 234-258.

Bubser M, Backstrom JR, Sanders-Bush E, Roth BL, Deutch AY (2001). Distribution of serotonin 5-HT(2A) receptors in afferents of the rat striatum. Synapse 39: 297-304.

Burnet PW, Eastwood SL, Harrison PJ (1996). 5-HT1A and 5-HT2A receptor mRNAs and binding site densities are differentially altered in schizophrenia. Neuropsychopharmacology 15: 442-455.

Carlsson ML (1995). The selective 5-HT2A receptor antagonist MDL 100,907 counteracts the psychomotor stimulation ensuing manipulations with monoaminergic, glutamatergic or muscarinic neurotransmission in the mouse-implications for psychosis. J Neural Transm 100: 225-237.

Carlsson ML, Martin P, Nilsson M, Sorensen SM, Carlsson A, Waters $S$ et al (1999). The 5-HT2A receptor antagonist M100907 is more effective in counteracting NMDA antagonist- than dopamine agonist-induced hyperactivity in mice. J Neural Transm 106: 123-129.

de Angelis L (2002). 5-HT2A antagonists in psychiatric disorders. Curr Opin Investig Drugs 3: 106-112.

de Paulis T (2001). M-100907 (Aventis). Curr Opin Investig Drugs 2: $123-132$.

Dulawa SC, Hen R, Scearce-Levie K, Geyer MA (1997). Serotonin1B receptor modulation of startle reactivity, habituation, and prepulse inhibition in wild-type and serotonin1B knockout mice. Psychopharmacology 132: 125-134.

Gainetdinov RR, Jones SR, Caron MG (1999). Functional hyperdopaminergia in dopamine transporter knock-out mice. Biol Psychiatry 46: 303-311.

Gainetdinov RR, Mohn AR, Bohn LM, Caron MG (2001). Glutamatergic modulation of hyperactivity in mice lacking the dopamine transporter. Proc Natl Acad Sci USA 98: 11047-11054.
Gainetdinov RR, Sotnikova TD, Caron MG (2002). Monoamine transporter pharmacology and mutant mice. Trends Pharmacol Sci 23: 367-373.

Geyer MA (1998). Behavioral studies of hallucinogenic drugs in animals: implications for schizophrenia research. Pharmacopsychiatry 31(suppl 2): 73-79.

Geyer MA, Krebs-Thomson K, Braff DL, Swerdlow NR (2001). Pharmacological studies of prepulse inhibition models of sensorimotor gating deficits in schizophrenia: a decade in review. Psychopharmacology 156: 117-154.

Giros B, Jaber M, Jones SR, Wightman RM, Caron MG (1996). Hyperlocomotion and indifference to cocaine and amphetamine in mice lacking the dopamine transporter. Nature 379: 606-612.

Gurevich EV, Joyce JN (1997). Alterations in the cortical serotonergic system in schizophrenia: a postmortem study. Biol Psychiatry 42: 529-545.

Hoffman HS, Ison JR (1980). Reflex modification in the domain of startle: I. Some empirical findings and their implications for how the nervous system processes sensory input. Psychol Rev 87: 175-189.

Hoyer D, Hannon JP, Martin GR (2002). Molecular, pharmacological and functional diversity of 5-HT receptors. Pharmacol Biochem Behav 71: 533-554.

Hoyer D, Martin GR (1996). Classification and nomenclature of 5-HT receptors: a comment on current issues. Behav Brain Res 73: $263-268$

Jakab RL, Goldman-Rakic PS (1998). 5-Hydroxytryptamine2A serotonin receptors in the primate cerebral cortex: possible site of action of hallucinogenic and antipsychotic drugs in pyramidal cell apical dendrites. Proc Natl Acad Sci USA 95: 735-740.

Kehne JH, Baron BM, Carr AA, Chaney SF, Elands J, Schmidt CJ (1996). Preclinical characterization of the potential of the putative atypical antipsychotic MDL 100,907 as a potent 5-HT2A antagonist with a favorable CNS safety profile. J Pharmacol Exp Ther 277: 968-981.

Laruelle M (2000). The role of endogenous sensitization in the pathophysiology of schizophrenia: implications from recent brain imaging studies. Brain Res Brain Res Rev 31: 371-384.

Levitan RD, Masellis M, Basile VS, Lam RW, Jain U, Kaplan AS et al (2002). Polymorphism of the serotonin-2A receptor gene (HTR2A) associated with childhood attention deficit hyperactivity disorder (ADHD) in adult women with seasonal affective disorder. J Affect Disord 71: 229-233.

Liegeois JF, Ichikawa J, Meltzer HY (2002). 5-HT(2A) receptor antagonism potentiates haloperidol-induced dopamine release in rat medial prefrontal cortex and inhibits that in the nucleus accumbens in a dose-dependent manner. Brain Res 947: $157-165$.

Lucas G, Spampinato U (2000). Role of striatal serotonin2A and serotonin2C receptor subtypes in the control of in vivo dopamine outflow in the rat striatum. J Neurochem 74: 693-701.

Marcus MM, Nomikos GG, Svensson TH (2000). Effects of atypical antipsychotic drugs on dopamine output in the shell and core of the nucleus accumbens: role of 5-HT(2A) and alpha(1)adrenoceptor antagonism. Eur Neuropsychopharmacol 10: 245-253.

McMahon LR, Cunningham KA (2001). Antagonism of 5-hydroxytryptamine(2a) receptors attenuates the behavioral effects of cocaine in rats. J Pharmacol Exp Ther 297: 357-363.

Meltzer HY (1999). The role of serotonin in antipsychotic drug action. Neuropsychopharmacology 21: 106S-115S.

Moser PC, Moran PM, Frank RA, Kehne JH (1996). Reversal of amphetamine-induced behaviours by MDL 100,907, a selective 5-HT2A antagonist. Behav Brain Res 73: 163-167.

Ngan ET, Yatham LN, Ruth TJ, Liddle PF (2000). Decreased serotonin $2 \mathrm{~A}$ receptor densities in neuroleptic-naive patients with schizophrenia: a PET study using [(18)F] setoperone. Am J Psychiatry 157: 1016-1018. 
Offord SJ, Wong DF, Nyberg S (1999). The role of positron emission tomography in the drug development of M100907, a putative antipsychotic with a novel mechanism of action. J Clin Pharmacol 39: 17S-24S.

O'Neill MF, Heron-Maxwell CL, Shaw G (1999). 5-HT2 receptor antagonism reduces hyperactivity induced by amphetamine, cocaine, and MK-801 but not D1 agonist C-APB. Pharmacol Biochem Behav 63: 237-243.

Padich RA, McCloskey TC, Kehne JH (1996). 5-HT modulation of auditory and visual sensorimotor gating: II. Effects of the 5-HT2A antagonist MDL on disruption of sound and light prepulse inhibition produced by $5-\mathrm{HT}$ agonists in Wistar rats. Psychopharmacology 124: 107-116.

Palfreyman MG, Schmidt CJ, Sorensen SM, Dudley MW, Kehne JH, Moser P et al (1993). Electrophysiological, biochemical and behavioral evidence for 5-HT2 and 5-HT3 mediated control of dopaminergic function. Psychopharmacology 112: S60-S67.

Paulus MP, Geyer MA (1991). A temporal and spatial scaling hypothesis for the behavioral effects of psychostimulants. Psychopharmacology 104: 6-16.

Pehek EA, McFarlane HG, Maguschak K, Price B, Pluto CP (2001). M100,907, a selective 5-HT(2A) antagonist, attenuates dopamine release in the rat medial prefrontal cortex. Brain Res 888: 51-59.

Perry W, Minassian A, Feifel D, Braff DL (2001). Sensorimotor gating deficits in bipolar disorder patients with acute psychotic mania. Biol Psychiatry 50: 418-424.

Porras G, Di Matteo V, Fracasso C, Lucas G, De Deurwaerdere P, Caccia $S$ et al (2002). 5-HT2A and 5-HT2C/2B receptor subtypes modulate dopamine release induced in vivo by amphetamine and morphine in both the rat nucleus accumbens and striatum. Neuropsychopharmacology 26: 311-324.

Ralph RJ, Paulus MP, Fumagalli F, Caron MG, Geyer MA (2001). Prepulse inhibition deficits and perseverative motor patterns in dopamine transporter knock-out mice: differential effects of D1 and D2 receptor antagonists. J Neurosci 21: 305-313.

Ralph RJ, Varty GB, Kelly MA, Wang YM, Caron MG, Rubenstein $M$ et al (1999). The dopamine D2, but not D3 or D4, receptor subtype is essential for the disruption of prepulse inhibition produced by amphetamine in mice. J Neurosci 19: 4627-4633.

Remington G, Kapur S (2000). Atypical antipsychotics: are some more atypical than others? Psychopharmacology 148: 3-15.
Scatton B, Sanger DJ (2000). Pharmacological and molecular targets in the search for novel antipsychotics. Behav Pharmacol 11: $243-256$

Serretti A, Cusin C, Lorenzi C, Lattuada E, Lilli R, Smeraldi E (2000). Serotonin-2A receptor gene is not associated with symptomatology of schizophrenia. Am J Med Genet 96: 84-87.

Sipes TE, Geyer MA (1997). DOI disrupts prepulse inhibition of startle in rats via 5-HT2A receptors in the ventral pallidum. Brain Res 761: 97-104.

Sorensen SM, Kehne JH, Fadayel GM, Humphreys TM, Ketteler HJ, Sullivan CK et al (1993). Characterization of the 5-HT2 receptor antagonist MDL 100907 as a putative atypical antipsychotic: behavioral, electrophysiological and neurochemical studies. J Pharmacol Exp Ther 266: 684-691.

Spielewoy C, Roubert C, Hamon M, Nosten-Bertrand M, Betancur C, Giros B (2000). Behavioural disturbances associated with hyperdopaminergia in dopamine-transporter knockout mice. Behav Pharmacol 11: 279-290.

Swerdlow NR, Geyer MA (1998). Using an animal model of deficient sensorimotor gating to study the pathophysiology and new treatments of schizophrenia. Schizophr Bull 24: 285-301.

Talvik-Lotfi M, Nyberg S, Nordstrom AL, Ito H, Halldin C, Brunner $\mathrm{F}$ et al (2000). High 5HT2A receptor occupancy in M100907-treated schizophrenic patients. Psychopharmacology 148: 400-403.

Varty GB, Bakshi VP, Geyer MA (1999). M100907, a serotonin 5HT2A receptor antagonist and putative antipsychotic, blocks dizocilpine-induced prepulse inhibition deficits in SpragueDawley and Wistar rats. Neuropsychopharmacology 20: 311-321.

Wadenberg MG, Browning JL, Young KA, Hicks PB (2001). Antagonism at 5-HT(2A) receptors potentiates the effect of haloperidol in a conditioned avoidance response task in rats. Pharmacol Biochem Behav 68: 363-370.

Wadenberg ML, Hicks PB, Richter JT, Young KA (1998). Enhancement of antipsychotic-like properties of raclopride in rats using the selective serotonin2A receptor antagonist $\mathrm{MDL}$ 100,907. Biol Psychiatry 44: 508-515.

Williams J, Spurlock G, McGuffin P, Mallet J, Nothen MM, Gill M et al (1996). Association between schizophrenia and T102C polymorphism of the 5-hydroxytryptamine type 2a-receptor gene. European Multicentre Association Study of Schizophrenia (EMASS) Group. Lancet 347: 1294-1296. 